\title{
WTO Membership for China: \\ To Be and Not to Be: Is that the Answer?
}

Sylvia Ostry

\section{Introduction}

Canada is the member of the G7 countries most dependent on trade. The rules-based trading regime under the World Trade Organization (WTO) is critical for Canada's continuing prosperity. The biggest issue currently facing the world trading system is the accession of China, which will bring a fifth of the world's population into the system. This will obviously have widespread implications for the overall system, which will be of overarching importance for Canada. Given this importance and the lifelong interest of David Slater in trade issues, this paper focuses on the myriad of issues raised by China's accession to the WTO.

The negotiations for China's accession to the WTO have gone on, albeit in fits and starts, for almost 15 years. But as the saying goes, timing is everything. If China had joined the General Agreement on Tariffs and Trade (GATT), the negotiations would have been far easier since market access under GATT was mainly about border barriers. But since the Uruguay Round the concept of market access has been extended to include not only domestic regulatory policies but also both substantive and procedural legal issues. The barriers to access for service providers stem from laws, regulations, administrative actions which impede cross-border trade and factor flows. Implicit in this shift embodied in the General Agreement on Trade in Services (GATS) is a move away from GATT negative regulation - what 
governments must not do - to positive regulation - what govern-ments must do. This aspect is now apparent in the WTO's telecommuni-cations reference paper that set out a common framework for the regulation of competition in basic telecommunications and is likely to be adopted in other sectors. In the case of intellectual property the move to positive regulation is more dramatic since the negotiations covered not only standards for domestic laws but also detailed provisions for procedures to enforce individual (meaning primarily corporate) property rights. But the Round also dealt with social regulation, which has grown so rapidly in the Organisation for Economic Co-operation and Development (OECD) countries since the 1970s that it has been termed "regulatory inflation". In the area of social regulation (covering environment, food safety, etc.) the positive regulatory approach is procedural rather than substantive and the model is the western, especially American, administrative procedures model, of which more will be said later.

The WTO rules thus involve commitments for many member countries to what is in effect systemic redesign. Further, and in my view most importantly, the overarching governing principle of the WTO trading system is the western system of law, especially its American version, and the WTO houses a supranational juridical system for settlement of disputes, a system which is becoming increasingly litigious.

But the transformation of the system is not the only aspect of timing worth noting. The political economy of post-Uruguay Round trade policy has also been transformed. The Uruguay Round was a north-south "grand bargain", GATT-type market access for the south, especially in agriculture and labour-intensive industries like textiles and clothing, in exchange for their acceptance of rules governing the so-called new issues of trade in services and intellectual property. The deal required investment in structural transformation often with uncertain, long-term returns. Unfortunately though, it turned out to be a bum deal in the view of many southern countries and has left a wide north-south divide. And that divide has been widening further with the demand for the "trade and" (environment and labour) issues by the north, largely in response to the new global actors: the NGOs (non-governmental organizations). However, not all the NGOs are the ones you see marching on TV. Some are technical/legal groups possessing a highly valuable strategic asset - policy knowledge - and a number act as a "virtual secretariat" for the south. In post-Seattle Geneva, a seemingly paralyzed north is confronted by an increasingly proactive south. The credibility and effectiveness of the WTO is under serious challenge. Thus the impact of Chinese accession must be viewed in this context.

Since Chinese accession will be arguably among the most significant events in the history of the world trading system and is bound to have a 
profound impact on the system surely both the WTO and the major trading countries have undertaken a careful analysis of the subject? Rather than give you a straight answer, let me recount a story. A few months age, I was at a conference at the University of Minnesota and asked a senior WTO official how many people in the secretariat were analyzing the impact of China on the operations of the WTO. He grinned (assuming I knew the answer) and said two people in the legal division were working "round the clock on technical accession matters". OK, I said, surely you have some studies from Brussels or Washington or ..... Nothing, he said, his grin fading. There are lots of studies by business groups on the benefits of opening up a market of over a billion consumers. And lots of models estimating the impact of Chinese liberalization on China and the world. These are studies of improved access for goods under the GATT, of course, and provide carefully calibrated numbers. (Many of the econometric studies are nearly breathless in admiration for the amazing extent and pace of Chinese liberalization and the bonanza of welfare gains, albeit with some costs for industries within China and many in Asia.) But studies on the WTO system? Alas, there are none.

So I am treading in unknown territory. And I want to break ranks with my fellow economists (except for the growing institutional school) and look at Chinese accession through a legal template. I will then put forward some necessarily speculative views on the implications of Chinese accession for the future of the WTO and end with a policy proposal to facilitate the full and effective integration of China into the world trading system.

\section{China and Transparency}

The WTO is a highly legalized system with a built-in tendency for further legalization. ${ }^{1}$ It can, for example, be observed in the growing evidentiary content of all disputes: panels are now in effect preparing reports less for the parties than for the Appellate Board. The requirement for ever-increasing amounts of detailed information has only just begun. Imagine what disputes in China's services sector or food safety and risk assessment would entail in terms of evidence. Or what about a dispute on subsidies in China's state owned enterprises (SOEs), privatized or not, which could include a demand for information on non-performing bank loans or the non-existent "services" of subsidiaries or cross-subsidization in telecommunications services or,

${ }^{1}$ Much of this discussion is from Ostry (1998, pp. 1-22). See also Groombridge and Barfield (1999).

WTO Membership for China 
technology transfer conditions for foreign investors, or $1 / 4$. But this aspect of so-called transparency is by no means the only problem. Far more important over the long run is the fundamental aspect of "transparency" as a pillar of the GATT and now the WTO, a pillar as important as non-discrimination in the origins of the system. This needs some explanation.

The drafting of the Charter of the International Trade Organization (ITO), which was to have been a part of the Bretton Woods institutional architecture, coincided with a new development in the American legal system, the establishment of the Administrative Procedures Act (APA) in 1946. The APA stemmed from the expansion of the role of government as a result of the New Deal and the war. It was, in effect, designed to constrain the discretionary power of bureaucrats. When the ITO died, the main elements of the APA, which had been included in the Charter, became article $\mathrm{X}$ of the GATT entitled "Publication and Administration of Trade Regulations". No founding member objected, probably because all industrial-ized countries had adapted similar legislation as a result of the expanded role of government. And all therefore required the establishment of norms to control what bureaucrats do and how they do it. However, it is important to underline that the U.S. approach was different in several respects in placing more emphasis on independent regulatory agencies with quasi-judicial or quasi-legislative functions; an emphasis on the right of notice and comment; freedom of information; and judicial review. The U.S. approach (more adversarial and fact-intensive than the European) was reflected in article X, although it is weaker than the APA in speaking of the desirability rather than the necessity of independent tribunals and judicial review, probably as a result of compromise in the negotiating process. In any case, it was hardly a major item in the negotiations because the GATT's focus was on border barriers, which are more obviously "transparent".

The Tokyo Round nudged transparency and legalization a bit further but the Uruguay Round introduced a sea change. So, for example, "transparency" - the word actually appears in the Agreement on Trade-Related Aspects of Intellectual Property Rights (TRIPS) - now requires the publication of laws, regulations and the mode of administration in services as well as detailed enforcement procedures in TRIPS. The Accession Protocol of China, of course, reflects these changes, including requirements on the administration of the trade regime and sections on transparency and judicial review.

Can China deliver on these requirements? The short answer would be not yet - and it is not clear when. Thus, transparency covers: publication of relevant laws and regulations; right of comment before implementation; enforcement only of those laws and regulations published; creation of a single inquiry point with a time limit for response. Unfortunately, while Beijing may 
be able to publish all central government laws, etc. it is widely agreed that many (an unknown number) of relevant state laws will not (cannot) be covered nor will the unpublished "normative documents", a leftover from the old regime, still in use by local and state officials. More broadly, the multilayered complexity of the evolving Chinese legal system - including several administrative laws - make it impossible to conform to WTO transparency. The Chinese laws at present lack specified procedures to constrain bureaucratic discretion and include no mandatory right of comment. Finally, the requirement for judicial review, which has been watered down in recent negotiations, faces the basic problem that there is no separation of powers in the constitution and therefore no concept of an independent judiciary. Indeed the Chinese Communist Party has the final say on judicial appointments. As several Chinese legal experts have noted, the Chinese tradition regards law as an instrument to maintain social discipline or promote policy or sovereign rights - rule by law not rule of law. And while that is certainly changing, the instrumentalist approach to law is still widely prevalent.

The concept of instrumentalism is deep-seated. Thus, the pervasiveness of local protectionism stems from the decentralization of the economic reform process launched in the 1980s. There was no view of systemic reform but rather ad hoc pragmatic evolution. The same approach applies to legal reform. Law is an instrument of policy: there is a large and growing body of legal rules for domestic and foreign transactions and government administration. There is, however, no legal system, no protection against arbitrary and unpredictable government decisions.

But many, including economists and corporations, would say: So what? There will be an endogenous demand for the rule of law from Chinese business and lawyers as it becomes clear that the costs of relations-based corporate governance, the norm in China, rises astronomically with the rapid spread of economic liberalization. So guanxi (connections) is a wasting asset and the rule of law is far less costly and more effective. Thus it is not the demand from the WTO, but the demand from business itself that will make the rule of law the governance norm in China. This issue is now the subject of debate among institutional economists and it is all very interesting. But guanxi is still prevalent, foreign corporations are actively engaged in forging relations-based networks, and during the transition from one to the other there seems to be what some have described as chaos. And there is growing evidence that corruption and red tape, that is, lack of transparency and the rule of hw, have a significant negative impact on foreign direct investment and on economic growth. ${ }^{2}$ So while obviously the transition will be lengthy,

${ }^{2}$ See Shang-Jin Wei (2000, pp. 303-346); and Shleifer (2000, pp. 347-351) for a 
the need for some clearly delineated time-certain road map will be of crucial importance both for sustained economic liberalization and sustained growth in China, and also for the WTO. I will make a proposal for such a transition mechanism before concluding, but first let us deal with the question of impact.

\section{Impact of Chinese Accession on the WTO}

In the light of the complexity and difficulty of the profound institutional change required if China is to abide by its WTO so-called transparency commitments it is worth noting that in the accession negotiations the United States, which had demanded a 16-year transition recently settled for eight years. In an article in Fortune magazine, Senior Statesman Lee Kuan Yew of Singapore notes the amazing transformation of China since 1978, but argues that to change the "mindset" of the Chinese rulers will require replacement by a new generation mainly educated abroad. He estimates this will take "20 to 30 years" (Lee Kuan Yew, 2000, p. 334). So maybe the WTO members know something that has escaped the notice of Lee Kuan Yew?

Seen through the prism of the legal template, the most significant impact of Chinese accession on the WTO will be on the dispute-settlement mechanism. I have already noted the endogenous legalization process at work and its increasingly evidentiary-intensive nature, which could create serious problems of access to reliable information in China. But it is also worth noting that the pressure from the United States and North American NGOs for the right to present amicus curiae briefs to both dispute panels and/or the Appellate Board is unlikely to abate. Indeed, a new rallying cry has been provided: "participatory legalism" (Shell, 1996, p. 370). Moreover there is now a major drive by some academic lawyers and NGOs to promote the primacy of customary international law over international trade law in the field of the environment as well as human rights (Ostry, 2001). Considering that China has just over 100,000 lawyers or about one for every 11,000 people compared with one per 300 in the United States, participatory legalism and endless arcane debates over whether or not customary international law should override the WTO may be a rather difficult game for China to play, let alone to win. (Strangely enough, however, it was reported in the Financial Times [2000, p. 8] that last year China decided to sharply reduce the number

fuller discussion of this point. 
of new lawyers because of concern over their growing potential for disruptiveness.)

So one view of the impact of Chinese accession expressed in the corridors in Geneva is that a flood of disputes could overwhelm the already over-burdened system. There is serious concern that China would likely regard these actions as political and, to save face, simply reject the process itself. Indeed, as many China scholars have underlined, Chinese foreign policy is deeply state-centric and protection of sovereignty is at its core. A Chinese rejection or attack on the dispute-settlement mechanism would seriously undermine its credibility.

But another view shared by some, especially multinational corporations with experience in China, is that there will be very few, if any, disputes. Businesses will be fearful of complaining to their governments because of retaliation by Chinese officials. They would prefer informal behind-the-scene, government-to-government talks so that some new deal could be worked out. This scenario would involve a two-track trading system: one set of transparent dispute-settlement rules for all WTO members except China and another set of opaque bilateral arrangements for China. Other countries India, for example - are likely to regard this as unfair to put it mildly.

Both scenarios could threaten the long-term viability of the WTO. Both would involve an indefinite period of "partial integration" for the Chinese to be and not to be. If that is a suggested answer it should be directly confronted. Surely a longer transition period, with clearly specified monitoring mechanisms and benchmarks as well as provisions for coordinated and targeted legal training assistance would be a more effective approach? A proposal along these lines will be described below. But one final point about impact requires exploration.

What impact will China have on the north-south gridlock over a new round of negotiations? I speculate that China will be pragmatic and carefully weigh the costs and benefits for China. Given the formidable structural change that will ensue from WTO accession - especially the impact on China's 900 million rural population and the widening rural-urban and inlandcoastal income inequality - it seems highly unlikely that further liberalization would be welcome, whatever the long-term welfare gains. Hence China is unlikely to be an active proponent of new negotiations. China sees itself as a leader of developing countries and there is likely to be some jousting with India over this high profile role. But on balance it seems unlikely that Chinese accession will be a positive factor in bridging the north-south divide. Perhaps a more innovation transition mechanism could help? 


\section{A New Transition Mechanism}

The Chinese accession negotiations with the two great trading powers - the European Union and the United States - have focused almost exclusively on market access for their (often competing) corporations. This is understandable, if regrettable, because au fond institutional or systemic issues are not a high priority. The alternative to a rules-based system is a power-based system and, unlike the postwar period when a combination of idealism and the Cold War fostered the creation of the international economic architecture, in today's post-Cold War environment commercial values rule supreme. But the same is not (or should not be) true for middle powers like Canada for whom a rules-based system is crucial to providing stability or at least reducing uncertainty. Canada played a lead role in the Uruguay Round in mobilizing middle-power coalitions that were effective in both launching and sustaining the extraordinarily difficult negotiations. And it was a Canadian proposal that created the WTO. The Chinese accession will have major consequences for the WTO and the world trading system. A middle-power coalition led by Canada could help mitigate the negative impact of accession both on the WTO and the Chinese reform process.

The accession protocol in Geneva already includes the concept of transition periods of varying length for different parts of the liberalization commitments. What is required is to house these specifics in an overall transition framework which would be time-certain; include specified benchmarks for review at designated dates by a WTO committee, which might take the form of either a new committee for economies in transition or of the existing Trade Policy Review (Groombridge and Barfield, 1999, pp. 76-81); and would result in full WTO membership at the end of the period when the TPRM certified full adherence to the transition protocol. To ensure the credibility of this mechanism the committee should have the right to apply sanctions for a specified period if China failed to deliver the commitments at any of the designated benchmarks.

This approach to accession (which should also apply to Russia where the institutional underpinning is far more chaotic and other transition economies in waiting) should be coordinated with World Bank programs. The technical assistance should be jointly supplied by the two institutions although this would require an increase in WTO training and legal resources. In addition, since China's integration into the WTO will involve major restructuring of the state owned enterprises; radical reform of the banking system; and the need to create an effective social safety net, coordination with Bank programs to 
facilitate this massive structural change would help ensure the sustainability of both the domestic reform and the liberalization process.

In addition to this more comprehensive transition arrangement, it would also be essential to include specific mechanisms to secure relevant information and to encourage mediation and negotiation for the settlement of seriously contentious disputes. But once again, it is important not to create a two-tier system in the WTO and thus the transitional arrangements with respect to dispute settlement should be time-certain in duration. But since the issue of the increasing litigiousness of the WTO dispute mechanism is a broader issue that the Chinese accession will amplify but does not create, it is likely to be discussed in the context of negotiations along with other issues of structural reform of the institution. Perhaps China could play a more positive role in the negotiations by working with other countries, like Canada, in strengthening the first post-Cold War institution and guardian of the rulesbased trading system, the WTO.

\section{References}

Financial Times (2000), "Beijing to Slash Number of New Lawyers", November 21, p. 8. Groombridge, M.A. and C. Barfield (1999), Tiger by the Tail: China and the World Trade Organization (Washington, DC: The AEI Press).

Ostry, S. (1998), "China and the WTO: The Transparency Issues", UCLA Journal of International Law and Foreign Affairs 3(1), 1-22.

(2001), "The WTO After Seattle: Something's Happening Here, What it is ain't Exactly Clear', American Economic Association, New Orleans, January, Preliminary Draft.

Shell, R. (1996), "The Trade Stakeholders Model and Participation by Nonstate Parties in the World Trade Organization", University of Pennsylvania Journal of International Economic Law 17(1), 370.

Shleifer, A. (2000), "Comment and Discussion: Local Corruption and Global Capital Flows", Brookings Paper on Economic Activity 2, 347-351.

Wei, Shang-Jin (2000), "Local Corruption and Global Capital Flows", Brookings Paper on Economic Activity 2, 303-346.

Yew, Lee Kuan (2000), “To be Rich is Glorious”, Fortune, November 13, 334.

WTO Membership for China 